\title{
Pengaruh Kompensasi dan Disiplin Kerja Terhadap Kinerja Karyawan Bagian Produksi PG. Meritjan Kediri.
}

\author{
Any Isvandiari \\ Dosen DPK Jurusan Manajemen STIE ASIA Malang \\ Lutfiatul Fuadah
}

\begin{abstract}
ABSTRAK
Penelitian ini bertujuan untuk mengetahui pengaruh variabel kompensasi dan disiplin kerja terhadap kinerja karyawan bagian produksi PG. Meritjan Kediri, baik secara parsial maupun simultan. Pengumpulan data dilakukan dengan menyebarkan kuesioner, penelitian yang dilakukan pada 77 orang responden bagian produksi, sampel seluruh karyawan bagian produksi PG. Meritjan Kediri. Dengan menggunakan skala likert, jawaban responden diolah dengan analisis regresi berganda, uji $t$, uji $F$ dan uji $R^{2}$.

Hasil penelitian ini menemukan bahwa ada pengaruh yang bermakna (signifikan) secara parsial antara variabel kompensasi dan variabel disiplin kerja terhadap variabel terikat kinerja karyawan serta ada pengaruh secara simultan variabel penelitian yang terdiri dari kompensasi dan disiplin kerja terhadap kinerja karyawan. Dari hasil yang ditemukan dalam penelitian ini maka pemimpin PG. Meritjan Kediri harus memperhatikan kompensasi, disiplin kerja dan mengawasi semua aktivitas karyawan untuk meningkatkan kinerja karyawan Bagian Produksi PG. Meritjan Kediri

Kata kunci : Kompensasi, Disiplin Kerja, Kinerja.
\end{abstract}

\section{ABSTRACT}

The research aims to know the effect of compensation variable and work discipline on the performance of the production employees PG. Meritjan Kediri, either partially or simultaneously. The data collected by distributing questionnaires, research conducted on 77 respondents production, samples from the production employees PG. Meritjan Kediri. By using a likert scale, the answer of respondentsbe treated used double regression analysis, $t$ test, $F$ test and $R^{2}$ test.

The results of this study found that there was a significant effect (significant) partially between the variables of compensation and work discipline variables on the dependent variable, and no influence employee performance variables simultaneously study consisted of compensation and work discipline on employee performance. From the results found in this study that the leaders should pay attention to PG. Meritjan Kediri compensation, work discipline and supervise all activities of employees to improve employee performance Part Production PG. Meritjan Kediri

Keywords : Compensation, Work Discipline, Performance.

\section{PENDAHULUAN}

Setiap perusahaan yang didirikan selalu memiliki tujuan yang berhak dicapai, secara umum tujuan yang diinginkan perusahaan adalah untuk mendapatkan keuntungan yang maksimal sehingga membantu tercapainya tujuan-tujuan lain.Usaha yang paling sederhana maupun usaha yang sangat kompleks akan membutuhkan tenaga manusia sebagai tenaga inti atau tenaga utama. Manusia merupakan penggerak utama perusahaan dalam mencapai tujuan perusahaan, oleh karena itu sumber daya manusia tidak dapat diganti fungsinya dengan peralatan lain.

Sumber daya yang memiliki perusahaan tidak akan memberikan hasil yang optimum apabila tidak didukung oleh sumber daya manusia yang mempunyai kinerja yang optimum. Douglas (2000) menjelaskan bahwa perusahaan membutuhkan karyawan yang mempunyai kinerja yang tinggi. Hal ini menunjukkan bahwa sumber daya manusia merupakan kunci pokok yang harus diperhatikan dengan segala kebutuhannya.

Memahami pentingnya keberadaan SDM di era global saat ini salah satu upaya yang harus dicapai oleh perusahaan adalah dengan meningkatkan kualitas SDM. Dengan meningkatkan kualitas sumber daya manusia diharapkan karyawan dapat meningkatkan kinerjanya. Kinerja karyawan merupakan suatu tindakan yang dilakukan karyawan dalam melaksanakan pekerjaan yang diberikan perusahaan (Handoko, 2008). Menurut Siagian (2002) bahwa kinerja karyawan dipengaruhi oleh beberapa faktor yaitu gaji, lingkungan kerja, budaya organisasi, kepemimpinan dan motivasi kerja, disiplin kerja, kepuasan kerja, komunikasi dan faktor-faktor lainnya.

Tujuan perusahaan itu tercapai tidak hanya tergantung pada peralatan serta sarana maupun prasarana yang lengkap, namun lebih kepada faktor manusia tersebut dalam mencapai suatu tujuan. Setiap karyawan yang memiliki kinerja yang tinggi dan baik dapat berkontribusi 
untuk mencapai tujuan serta sasaran-sasaran yang telah ditetapkan oleh perusahaan.Selain itu suasana tempat kerja yang nyaman, pemberian motivasi, penciptaan disiplin kerja yang baik dan kompensasi yang sesuai kepada setiap karyawan, akan dapat meningkatkan semangat karyawan dalam bekerja.

Menurut Budi Setiyawan dan Waridin (2006) kinerja karyawan merupakan hasil atau prestasi kerja karyawan yang nilai dari segi kualitas maupun kuantitas berdasarkan standar kerja yang ditentukan oleh pihak organisasi. Kinerja yang baik adalah kinerja yang optimal, yaitu kinerja yang sesuai standar organisasi dan mendukung tercapainya tujuan organisasi. Organisasi yang baik adalah organisasi yang berusaha meningkat kemampuan sumber daya manusianya, karena hal tersebut merupakan faktor kunci untuk meningkatkan kinerja karyawan.

Kinerja karyawan yang tinggi sangatlah diharapkan oleh perusahaan tersebut. Semakin banyak karyawan yang mempunyai kinerja tinggi, maka produktivitas perusahaan secara keseluruhan akan meningkat sehingga perusahaan akan dapat bertahan dalam persaingan global. Menurut Simamora, faktorfaktor yang digunakan dalam pengukuran kinerja ada tiga yakni: kuantitas kerja, kualitas kerja, dan ketepatan waktu.

Rendahnya tingkat kinerja karyawan dalam suatu perusahaan dapat dilihat dari besaran gaji maupun tunjangan yang diberikan oleh perusahaan dengan besarnya tanggung jawab pekerjaan yang dilakukan selain itu tingkat kehadiran ditempat kerja yang diakibatkan oleh kurangnya disiplin kerja karyawan serta penggunaan waktu secara tidak efektif dalam melaksanakan pekerjaan juga dikatakan sebagai rendahnya tingkat kinerja karyawan. Untuk itu pimpinan perusahaan perlu mengawasi setiap perilaku maupun tindakan yang dilakukan oleh seluruh karyawan pada saat bekerja. Kedisplinan adalah suatu sikap tingkah laku dan perbuatan yang sesuai dengan peraturan dari perusahaan baik tertulis maupun tidak tertulis. (Alex Nitisemito, 2000)

Disiplin tidak mungkin dapat ditegakkan bila peraturan yang dibuat hanya berdasarkan instruksi lisan yang dapat berubahubah sesuai dengan kondisi dan situasi. Dengan adanya aturan tertulis yang jelas, para pegawai akan mendapatkan kepastian mengenai pedoman apa saja yang boleh dilakukan dan tidak boleh dilakukan. Sehingga akan menghindarkan diri dari perilaku yang tidak sesuai dengan peraturan tersebut.

Disamping disiplin kerja peningkatan kinerja karyawan juga dapat dilakukan dengan cara pemberian kompensasi, karena adanya pemberian kompensasi karyawan menjadi lebih bersemangat untuk bekerja semaksimal mungkin. Salah satunya dengan meningkatkan kinerja karyawan melalui pemberian kompensasi yang sesuai dengan balas jasa kepada karyawan atas usaha mereka lakukan kepada perusahaan. Kompensasi adalah semua pendapatan yang terbentuk uang, barang langsung atau tidak langsung yang diterima karyawan sebagai imbalan atas jasa yang diberikan kepada perusahaan. Program kompensasi mencerminkan upaya organisasi untuk mempertahankan sumber daya yang dimiliki.

Kompensasi merupakan hal yang sensitif bila dikaitkan dengan kelayakan dalam memenuhi kebutuhan, apalagi semakin besarnya tingkat kebutuhan saat ini sehingga gaji yang diberikan masih dirasa kurang cukup. Pemberian kompensasi yang makin baik akan mendorong karyawan untuk bekerja dengan makin baik dan produktif (Hasibuan, 2012:118). Bentuk-bentuk kompensasi terbagi dalam beberapa bentuk yaitu Kompensasi finansial langsung, terdiri dari gaji, komisi dan bonus, kompensasi finansial tidak langsung terdiri dari tunjangan-tunjangan, asuransi, fasilitas, uang cuti liburan, dan kompensasi non finansial (Darsono dan Siswandoko, 2011:269). Kompensasi yang diberikan oleh PG. Meritjan Kediri yaitu berupa gaji, insentif, penghargaan dan tunjangan. Dimana pemberian gaji berdasarkan latar belakang pendidikan dan masa kerja pada klasifikasi golongan gaji pegawai. Tunjangan tersebut berupa tunjangan kesehatan dan jiwa.

Mengenai disiplin kerja pada PG. Meritjan Kediri yang masih sering terjadi pelanggaran yaitu sering datang terlambat pada jam masuk kerja, sering tidak masuk kerja/ bolos setelah libur panjang, dan kadang-kadang dalam penyelesaian pekerjaan tidak sesuai dengan standar dan waktu yang telah ditentukan. Untuk meningkatkan disiplin kerja PG.. Meritjan Kediri, atasan memberikan sanksi atas pelanggaran yang dilakukan karyawan dengan memberikan SP (Surat Peringatan) dan memberikan teguran secara langsung.Karyawan belum sepenuhnya menyadari bahwa disiplin sangat berpengaruh terhadap kemajuan organisasi perusahaan dan prestasi kerja mereka.

PG. Meritjan Kediri yang bergerak pangan. Produk yang dihasilkan meliputi gula kristal putih. Musim giling di PG. Meritjan Kediri ini dilakukan bulan Mei-November. Memperhatikan dari rendahnya tingkat kinerja diatas juga terjadi pada PG. Meritjan Kediri mengenai fenomena yang terjadi terkait dengan rendahnya kedisiplinan dan kompensasi yang 
menjadi faktor penyebab kinerja karyawan belum optimal di dalam menyelesaikan pekerjaan secara tepat waktu. Menurut sumber blok PG. Meritjan Kediri, pada tahun 2009 sampai 2012, jumlah produksi gula yang digiling mengalami penurunan. Dimana pada tahun 2009 jumlah produksi gula mencapai 35.000ton dan jumlah produksi gula pada tahun 2012 yaitu 25.000 ton.

Untuk karyawan tetap bagian produksi PG. Meritjan Kediri diberikan berbagai macam fasilitas dan tunjangan-tunjangan. Bonus juga diberikan apabila kapasitas produksi gula melebihi jumlah standar dalam masa giling. untuk karyawan tetap bagian produksi PG. Meritjan Kediri kenaikan pangkat atau jabatan ditentukan oleh pusat atau direksi yang bertempat disurabaya. Ketika musim giling berlangsung maka semua karyawan harus siap sedia kapanpun ketika dibutuhkan.

Mengingat bahwa peningkatan kinerja karyawan akan membawa kemajuan bagi perusahaan untuk dapat bertahan suatu persaingan lingkungan bisnis yang tidak stabil. Oleh karena itu upaya-upaya untuk meningkatkan kinerja karyawan merupakan tantangan manajemen yang paling serius karena keberhasilan untuk mencapai tujuan dan kelangsungan hidup perusahaan tergantung pada kualitas kinerja sumber daya manusia yang didalamnya.

Melihat dari uraian diatas, maka peneliti melakukan penelitian yang berjudul "Pengaruh Kompensasi dan Disiplin Kerja terhadap Kinerja Karyawan Bagian Produksi di PG.. Meritjan Kediri”.

Rumusan Masalah

1. Bagaimana pengaruh kompensasi dan disiplin kerja secara parsial terhadap kinerja karyawan bagian produksi di PG. Meritjan Kediri?

2. Bagaimana pengaruh kompensasi dan disiplin kerja secara simultan terhadap kinerja karyawan bagian produksi di PG. Meritjan Kediri?

\section{Landasan Teori \\ Kompensasi}

Kompensasi merupakan segala sesuatu bentuk imbalan yang diterima oleh seseorang (pekerja) sebagai imbalan atas kerja mereka. (Darsono dan Siswandoko, 2011:269).

\section{Disiplin Kerja}

Menurut Alex Nitisemito (2000:200)

kedisplinan adalah suatu sikap tingkah laku dan perbuatan yang sesuai dengan peraturan dari perusahaan baik tertulis maupun tidak tertulis.

\section{Kinerja}

Mangkunegara (2006 : 20) menyatakan, "Kinerja adalah hasil kerja secara kualitas dan kuantitas yang dicapai oelh seseorang pegawai dalam melaksanakan tugasnya sesuai dengan tanggung jawab yang diberikan kepadanya”.

\section{Kerangka Konseptual dan Perumusan Hipotesis}

Berdasarkan pada teori-teori di atas maka dapat dirumuskan kerangka konseptual dari penelitian seperti pada gambar di bawah ini

Gambar 1

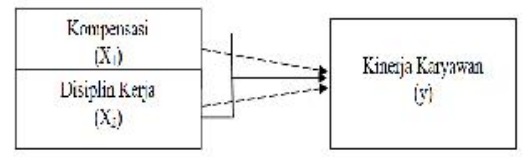

Keterangan :

$\underset{\text { y secara simultan }}{\longrightarrow}$ : Pengaruh variabel $x$ terhadap
y secara parsial

Hipotesis :

$\mathrm{H}_{1} \quad$ : Diduga kompensasi $\left(\mathrm{X}_{1}\right)$ dan disiplin kerja $\left(\mathrm{X}_{2}\right)$ berpengaruh secara parsial terhadap kinerja karyawan bagian produksi PG.. Meritjan Kediri.

$\mathrm{H}_{2} \quad$ : Diduga kompensasi $\left(\mathrm{X}_{1}\right)$ dan disiplin kerja $\left(\mathrm{X}_{2}\right)$ berpengaruh secara simultan terhadap kinerja karyawan bagian produksi PG.. Meritjan Kediri.

\section{Metode Penelitian \\ Lokasi Penelitian}

Lokasi penelitian merupakan objek dimana penelitian dilakukan oleh peniliti. Penelitian ini bertempat di Desa Meritjan Kec.Mojoroto Kota Kediri.

\section{Jenis Penelitian}

Jenis penelitian yang dilakukan ini adalah penelitian kausal atau sebab akibat yang berguna untuk menganalisis hubunganhubungan antar variabel satu dengan yang lainnya. Berdasarkan uraian tersebut, maka desain riset kausal mengarah pada terjadinya hubungan sebab akibat antara variabel-variabel bebas (X) yaitu kompensasi dan disiplin kerja terhadap variabel terikat (Y) yaitu kinerja karyawan Bagian Produksi PG. Meritjan Kediri. Populasi dan Sampel

\section{a. Populasi}

Menurut Simamora (2004:195) populasi ialah sekumpulan satuan analisis yang di dalamnya terkandung informasi yang ingin diketahui. Sedangkan menurut Sugiyono (2003:72) "Populasi adalah wilayah generalisasi yang terdiri atas objek/subyek yang mempunyai kualitas dan karakteristik tertentu yang ditetapkan oleh peneliti untuk dipelajari dan kemudian ditarik kesimpulannya. Adapun populasi penelitian ini yaitu karyawan bagian 
produksi pada PG. Meritjan Kediri yaitu sebanyak 77 karyawan.

\section{a. Sampel}

Menurut Arikunto (2006:131) "Sampel penelitian adalah sebagian atau wakil populasi yang diteliti". Sedangkan menurut Sugiyono (2003:73) "Sampel adalah bagian dari jumlah karakteristik yang dimiliki oleh populasi tersebut". Penentuan jumlah sampel menurut Arikunto (2002:112) apabila jumlah subyeknya kurang dari 100 orang lebih baik diambil semua, sehingga penelitiannya merupakan penelitian populasi dengan jumlah sampel yang diambil sebanyak 77 responden bagian produksi pada PG. Meritjan Kediri maka disebut sampel jenuh.

\section{Jenis dan Sumber Data}

a. Jenis Data

Jenis data yang digunakan dalam penelitian ini adalah jenis data kuantitatif yang berasal dari data kualitatif (menyebarkan angket ke responden) yang dikuantitatifkan agar dapat diproses menggunakan statistik. Menurut Sugiyono (2011:8), kuantitatif adalah metode penelitian yang berlandaskan filsafat positisme, yang digunakan untuk meneliti pada populasi atau sampel tertentu, pengumpulan data menggunakan instrumen penelitian, analisis data bersifat kuantitatif, penggunaan statistik dengan tujuan untuk menguji hipotesis yang ditetapkan.

b. Sumber Data

Berdasarkan sumber memperolehnya data dalam penelitian ini dibagi menjadi dua yaitu:

\section{Data Primer}

Menurut Nasution (2003:143), data primer adalah data yang diperoleh langsung dari lapangan. Dalam penelitian ini data primer yang digunakan bersumber dari responden yang merupakan karyawan bagian produksi PG. Meritjan Kediri, yang terdiri dari identitas responden, tanggapan responden, terhadap kompensasi, disiplin kerja, dan kinerja karyawan melalui kuisioner, observasi dan interview.

\section{Data Sekunder}

Data sekunder adalah data yang bukan diusahakan sendiri penelitiannya, seperti jumlah karyawan, struktur organisasi maupun sejarah perusahaan. Data sekunder diperoleh dari perusahaan yang dapat dilihat dokumentasi perusahaan, buku-buku referensi dan informasi lain yang berhubungan dengan penelitian. Data yang diperoleh dari internet seperti visi misi PTPN X, visi misi PG. Meritjan Kediri dan logo PTPN X.

\section{Metode Pengumpulan Data}

Didalam penelitian ini metode pengumpulan data yang digunakan adalah kuesioner. Kuesioner adalah cara atau teknik pengumpulan data dengan melakukan penyebaran angket yang berisi daftar pertanyaan yang telah dipersiapkan kepada responden secara acak. Tujuan utama dari penyebaran angket ini adalah untuk memperoleh informasi yang relevan tentang tujuan survei.

Hasil kuesioner akan telihat dalam angka, tabel, analisis statistik dan uraian dari hasil penelitian. Selanjutnya kuesioner diuji dahulu, karena ketepatan pengujian suatu hipotesis tentang hubungan dan pengaruh antar variabel penelitian tergantung pada kualitas data yang dipakai dalam pengujian tersebut. Untuk lebih menjamin hasil yang telah memuaskan selain dilakukan dengan uji korelasi juga digunakan prinsip-prinsip pengukuran untuk melihat kesahihan (validitas), kepraktisan dan kehandalan (reliabilitas) pernyataan akan dikirim ke responden.

\section{Hasil dan Pembahasan \\ Analisis Validitas dan Reliabilitas}

Dalam penelitian ini, cara untuk mengetahui butir pertanyaan dalam instrument telah valid atau tidak adalah dengan membandingkan signifikansi masing- masing butir pertanyaan dengan taraf signifikansi. Dari hasil analisis menunjukan semua item pertanyaan valid. Tingkat reliabilitas data diuji dengan nilai Alpha Cronbach. Suatu instrumen dikatakan reliable jika mempunyai nilai Alpha Cronbach > 0,50. Hasil uji reliabilitas untuk masing - masing variabel menunjukan semua variabel reliabel.

\section{Analisis Korelasi}

Analisis korelasi antar variabel penelitian menggambarkan nilai masing - masing variabel dilihat dari Pearson Correlation dengan tingkat signifikan sebesar 0,05 yang artinya ada hubungan antar variabel.

\section{Uji Analisis Regresi Linier Berganda}

Analisis regresi berganda ditujukan untuk memprediksi seberapa jauh pengaruh dua variabel bebas atau lebih terhadap variabel terikat.

Tabel 1

\section{Hasil Pengujian Regresi Berganda}

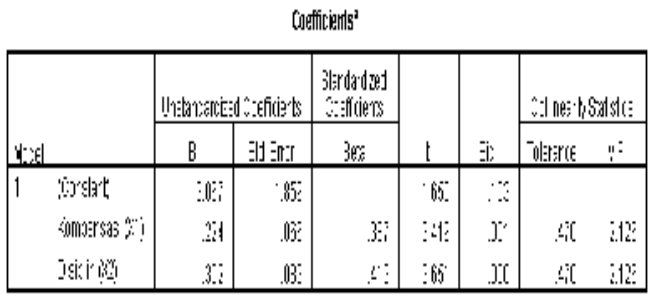

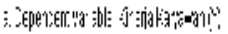

Sumber : Data diolah (2016)

Persamaan regresi yang digunakan dalam penelitian ini yaitu: $Y=a+b_{1} X_{1}+b_{2} X_{2}+e$ 
Maka dari tabel 1 diperoleh hasil sebagai berikut:

$\mathrm{Y}=3.067+0.224 \mathrm{X}_{1}+0.302 \mathrm{X}_{2}+1.859$

Dari persamaan regresi tersebut dapat diuraikan sebagai berikut :

a. $\quad$ Konstanta (a) $=3.067$ artinya kinerja karyawan Bagian Produksi PG. Meritjan Kediri akan bernilai sebesar 3.067 jika variabel kompensasi $\left(\mathrm{X}_{1}\right)$ dan disiplin kerja $\left(\mathrm{X}_{2}\right)$ tidak ikut mempengaruhi kinerja karyawan Bagian produksi PG. Meritjan Kediri. Atau dengan kata lain jika semua variabel independen bernilai nol, maka kinerja karyawan akan bernilai 3.067. b. Koefisien regresi $\mathrm{X}_{1}=0.224$ artinya setiap peningkatan (penambahan) $1 \%$ variabel kompensasi $\left(\mathrm{X}_{1}\right)$ akan meningkatkan kinerja karyawan Bagian Produksi PG. Meritjan Kediri (Y) sebesar 0.224. Dengan asumsi sub variabel disiplin kerja $\left(\mathrm{X}_{2}\right)$ konstan. Jika variabel kompensasi $\left(\mathrm{X}_{1}\right)$ ada kecenderungan meningkat, maka kinerja karyawan Bagian produksi PG. Meritjan Kediri akan meningkat. Jika variabel kompensasi $\left(\mathrm{X}_{1}\right)$ kecenderungan menurun, maka kinerja karyawan Bagian produksi PG. Meritjan Kediri juga akan menurun. Pada karyawan bagian Produksi PG. Meritjan Kediri gaji yang diterima oleh karyawan mengikuti UMR yang ada di Kota Kediri sebesar Rp. 1.600.000.

c. Koefisien regresi $\mathrm{X}_{2}=0.302$ artinya setiap peningkatan (penambahan) $1 \%$ variabel disiplin kerja $\left(\mathrm{X}_{2}\right)$ akan meningkatkan kinerja karyawan Bagian Produksi PG. Meritjan Kediri (Y) sebesar 0.302. Dengan asumsi variabel kompensasi $\left(\mathrm{X}_{1}\right)$ konstan. Jika variabel disiplin kerja $\left(\mathrm{X}_{2}\right)$ ada kecenderungan meningkat, maka kinerja karyawan Bagian Produksi PG. Meritjan Kediriakan meningkat. Jika variabel disiplin kerja $\left(\mathrm{X}_{2}\right)$ kecenderungan menurun, maka kinerja karyawan Bagian Produksi PG. Meritjan Kediri juga akan menurun. Mengenai disiplin kerja apabila ada karyawan yang terlambat solusinya adalah memberikan sanksi atau teguran secara langsung dan menberikan motivasi-motivasi agar karyawan tersebut tidak datang terlambat dan disiplin kerja. Karena kinerja karyawan dipengaruhi juga disiplin kerja karyawannya, apabila karyawannya disiplin maka kinerja perusahaan juga akan baik atau meningkat mencapai target yang diinginkan oleh perusahaaan.

d. Error term (e) $=1.859$ artinya setiap peningkatan (penambahan) akan kinerja karyawan Bagian Produksi PG. Meritjan Kediri (Y) selain dipengaruhi oleh kecenderungan meningkat atau menurunnya variabel kompensasi dan disiplin kerja ternyata dipengaruhi oleh variabel lain yang ikut mempengaruhi kinerja karyawan Bagian produksi PG. Meritjan Kediri (Y) sebesar 1.859 variabel lain yang dimaksudkan adalah variabel lain yang belum dibahas dalam penelitian ini. Dari persamaan regresi tersebut dapat dilihat bagaimana pengaruh variabel kompensasi $\left(\mathrm{X}_{1}\right)$ dan disiplin kerja $\left(\mathrm{X}_{2}\right)$ terhadap variabel kinerja karyawan Bagian Produksi PG. Meritjan Kediri (Y). Pengaruh positif menunjukkan bahwa variabel kompensasi $\left(\mathrm{X}_{1}\right)$ dan disiplin kerja $\left(\mathrm{X}_{2}\right)$ akan searah dengan perubahan variabel kinerja karyawan Bagian Produksi PG. Meritjan Kediri (Y). Sedangkan error term termasuk dalam variabel lain yang juga mempengaruhi kinerja karyawan Bagian Produksi PG. Meritjan Kediri (Y), namun belum ikut dibahas atau disinggung kepastiannya dalam penelitian sebagai pengaruh kinerja karyawan Bagaian Produksi PG. Meritjan Kediri.

\section{Uji Hipotesis}

\section{Uji t}

Uji t dilakukan untuk mengetahui signifikan dari pengaruh variabel - variabel bebas, yaitu kompensasi $\left(\mathrm{X}_{1}\right)$ dan disiplin kerja $\left(\mathrm{X}_{2}\right)$ secara parsial terhadap kinerja karyawan Bagian produksi PG. Meritjan Kediri (Y). Pengujian uji $\mathrm{t}$ yang dilakukan menggunakan tingkat signifikansi $\alpha=0.05$, dengan jumlah sampel (n) $=77$ orang dan jumlah variabel bebas $(\mathrm{k})=2$, sehingga degree of freedom (df) yang dihasilkan adalah $\mathrm{df}=\mathrm{n}-\mathrm{k}-1=77-2-1=74$. Hasil $t_{\text {tabel }}$ yang diperoleh adalah 1.992. Ketentuan yang digunakan adalah:

- Jika (-) $t_{\text {tabel }} \leq t_{\text {hitung }} \leq \mathrm{t}_{\text {tabel }}$, maka Ho diterima atau tidak berpengaruh signifikan/tidak berpengaruh secara nyata.

- Jika $t_{\text {hitung }}<(-) t_{\text {tabel }}$ atau $t_{\text {hitung }}>t_{\text {tabel }}$, maka Ho ditolak atau berpengaruh signifikan/berpengaruh secara nyata.

Tabel 2

Hasil Uji t

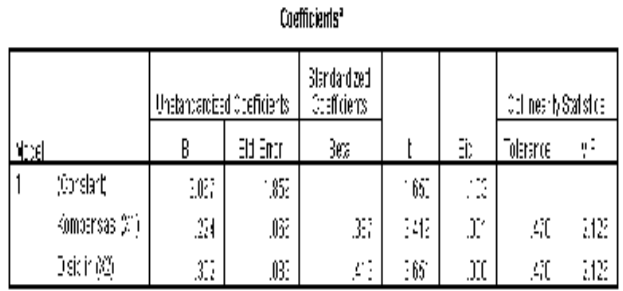

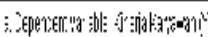

Sumber : Data diolah (2016)

Dengan menggunakan pengolahan data pada Tabel 2 dapat diuraikan sebagai berikut:

a. Variabel Kompensasi $\left(\mathrm{X}_{1}\right)$

Nilai $\mathrm{t}_{\text {hitung }}$ kompensasi adalah $3.419>\mathrm{t}_{\text {tabel }}$ 1.992 atau tingkat signifikan $\mathrm{t}$ adalah $0.001<$ tingkat signifikan $\alpha=0.05$, yang berarti Ho ditolak dan $\mathrm{Ha}$ diterima. Sehingga dapat disimpulkan pengaruh variabel kompensasi $\left(\mathrm{X}_{1}\right)$ terhadap kinerja karyawan Bagian Produksi PG. Meritjan Kediri (Y) adalah signifikan atau berpengaruh secara nyata. 
b. Variabel Disiplin Kerja $\left(\mathrm{X}_{2}\right)$

Nilai $t_{\text {hitung }}$ disiplin kerja adalah $3.651>$ $\mathrm{t}_{\text {tabel }} 1.992$ atau tingkat signifikan $\mathrm{t}$ disiplin kerja adalah $0.000<$ tingkat signifikan $\alpha=$ 0.05 , yang berarti Ho ditolak dan $\mathrm{Ha}$ diterima. Sehingga dapat disimpulkan pengaruh variabel disiplin kerja $\left(\mathrm{X}_{2}\right)$ terhadap kinerja karyawan Bagian Produksi PG. Meritjan Kediri (Y) adalah signifikan atau berpengaruh secara nyata.

Uji F atau Uji Simultan

Uji $F$ digunakan untuk mengetahui pengaruh variabel kompensasi $\left(\mathrm{X}_{1}\right)$ dan disiplin kerja $\left(\mathrm{X}_{2}\right)$ secara simultan (serentak) terhadap variabel kinerja karyawan Bagian produksi PG. Meritjan Kediri (Y). Pengujian ini menggunakan tingkat signifikansi $\alpha=0.05$, jumlah sampel $(n)=77$ dan jumlah variabel bebas $(\mathrm{k})=2$, dengan numerator $(\mathrm{df} 1)=2-1=$ 1 dan denumerator $(\mathrm{df} 2)=77-2=75$, sehingga $\mathrm{F}$ tabel yang diperoleh adalah 3.97 Ketentuan yang digunakan adalah:

- Jika $F_{\text {hitung }}<F_{\text {tabel }}$, maka Ho diterima atau tidak signifikan/tidak berpengaruh secara nyata.

- $\quad$ Jika $F_{\text {hitung }} \geq F_{\text {tabel}}$, maka Ho ditolak atau signifikan/berpengaruh secara nyata.

Tabel 3

\section{Hasil Uji F}

ANOW'

\begin{tabular}{|c|c|c|c|c|c|c|}
\hline Siodel & & $\begin{array}{c}\text { Sum of } \\
\text { 3quares } \\
\end{array}$ & $j$ & 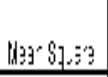 & $:$ & $\varepsilon$ \\
\hline \multirow[t]{3}{*}{1} & 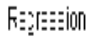 & : $: 6733$ & ? & $8^{\prime} .33 j$ & \multirow[t]{3}{*}{4561} & \multirow[t]{3}{*}{$.00)^{2}$} \\
\hline & Fi:idual & $2600 ; 3$ & $i 2$ & $3.3 j \mathrm{~J}$ & & \\
\hline & olla & 桜 6.005 & 16 & & & \\
\hline
\end{tabular}

a. Tedicors.((0)

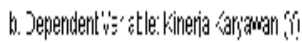

Sumber : Data diolah (2016)

Dari Tabel 3 dapat diuraikan bahwa $\mathrm{F}_{\text {hitung }}$ adalah $45.921>\mathrm{F}_{\text {tabel }}$ adalah 3.97 atau tingkat signifikan $\mathrm{F}$ adalah $0.000<$ tingkat signifikansi $\alpha=0.05$, yang berarti Ho ditolak dan Ha diterima. Sehingga dapat disimpulkan bahwa variabel kompensasi $\left(\mathrm{X}_{1}\right)$ dan disiplin kerja $\left(\mathrm{X}_{2}\right)$ secara bersama-sama berpengaruh terhadap kinerja karyawan Bagian Produksi PG. Meritjan Kediri (Y)

Uji Koefisien Determinasi $\left(\mathbf{R}^{2}\right)$

Uji koefisien determinasi untuk mengetahui besarnya pengaruh secara simultan variabel bebas penelitian yang terdiri dari kompensasi dan disiplin kerja terhadap kinerja karyawan.Hasil uji koefisien determinasi sebagai berikut :

Tabel 4

\section{Hasil Uji Koefisien Determinasi $\left(\mathbf{R}^{2}\right)$}

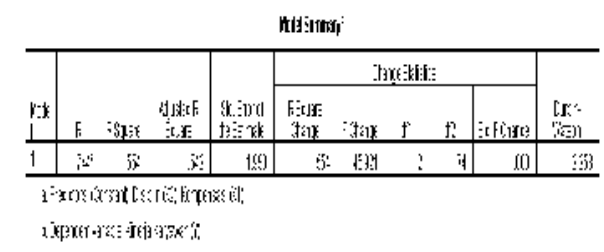

Sumber : Data diolah (2016)

Dari hasil analisis korelasi berganda seperti yang tercantum pada tabel di atas maka dapat dikemukakan bahwa nilai koefisien korelasi (R) yang diperoleh sebesar 0.744 dan bernilai positif menunjukkan bahwa terdapat hubungan yang kuat antara variabel kompensasi $\left(\mathrm{X}_{1}\right)$ dan disiplin kerja $\left(\mathrm{X}_{2}\right)$ dengan variabel kinerja karyawan (Y). Nilai positif menunjukkan adanya korelasi positif dimana jika variabel-variabel kompensasi $\left(\mathrm{X}_{1}\right)$ dan disiplin kerja $\left(\mathrm{X}_{2}\right)$ meningkat maka variabel kinerja karyawan (Y) juga akan meningkat (korelasi positif).

Besarnya nilai R Square yang diperoleh menunjukkan besarnya kontribusi variabelvariabel bebas dalam penelitian terhadap variabel terikat. Hasil analisis diperoleh nilai $\mathrm{R}$ Square sebesar 0,554 yang berarti variabelvariabel kompensasi $\left(\mathrm{X}_{1}\right)$ dan disiplin kerja $\left(\mathrm{X}_{2}\right)$ sebesar $55,4 \%$ mempunyai pengaruh terhadap kinerja anggota (Y), sedangkan sisanya $44,6 \%$ dijelaskan oleh variabel lain yang tidak diteliti dalam penelitian ini atau model.Seperti variabel lingkungan kerja, insentif dan motivasi kerja.

\section{Pembahasan}

Berdasarkan hasil penelitian dari analisis data yang telah dilakukan, menunjukkan antara kompensasi dan disiplin kerja secara bersamasama (simultan) berpengaruh secara signifikan atau nyata terhadap kinerja karyawan Bagian Produksi PG. Meritjan Kediri. Hal ini menegaskan bahwa sebagai suatu komponen dalam suatu lembaga/organisasi, kompensasi dan disiplin kerja memiliki peranan penting terhadap tingggi rendahnya kinerja karyawan. Dengan semakin meningkatnya atau semakin tinggi kompensasi dan disiplin kerja yang dimiliki karyawan Bagian Produksi ini akan mempengaruhi secara positif terhadap hasil kinerja karyawan Bagian Produksi PG.. Meritjan Kediri.

Terdapat hubungan yang signifikan atau nyata antara kompensasi terhadap kinerja karyawan Bagian Produksi PG. Meritjan Kediri. Dari indikator - indikator yang telah di ujikan pada karyawan Bagian Produksi PG. Meritjan Kediri, menunjukkan bahwa karyawan telah mampu dan menyadari akan pentingnya pemberian kompensasi dalam melaksanakan pekerjaannya dan telah mencapai target yang diinginkan oleh perusahaan. Kompensasi yang diberikan oleh karyawan Bagian Produksi PG. 
Meritjan Kediri, sudah baik tetapi hal ini haruslah selalu di perhatikan dan di tingkatkan lagi guna meningkatkan suatu kinerja karyawan.

Terdapat hubungan yang signifikan atau nyata antara disiplin kerja terhadap kinerja karyawan Bagian Produksi PG. Meritjan Kediri. Dari indikator- indikator yang telah di ujikan pada karyawan Bagian Produksi PG. Meritjan Kediri, menunjukkan bahwa karyawan telah mampu dan menyadari akan pentingnya disiplin dalam aktifitasnya melaksanakan dan mencapai tugas- tugas yang telah di targetkan oleh perusahaan. Kedisiplinan karyawan Bagian Produksi PG. Meritjan Kediri, sudah baik tetapi hal ini haruslah selalu di perhatikan dan di tingkatkan lagi guna meningkatkan suatu kinerja karyawan.

Suatu perusahaan khususnya PG. Meritjan Kediri, diharapkan dapat menunjukkan eksistensinya dalam hal yang positif artinya mampu menunjukkan kinerja yang baik di mata pihak luar khususnya masyarakat.

\section{Kesimpulan dan Saran}

1. Kesimpulan

Berdasarkan hasil penelitian yang telah dilakukan dapat diambil kesimpulan sebagai berikut:

a) Secara parsial variabel Kompensasi $\left(\mathrm{X}_{1}\right)$ dan disiplin kerja $\left(\mathrm{X}_{2}\right)$ berpengaruh secara nyata terhadap kinerja karyawan Bagaian Produksi PG. Meritjan Kediri (Y). Dengan pengaruh hubungan yang positif yang berarti apabila variabel kompensasi $\left(\mathrm{X}_{1}\right)$ dan disiplin $\operatorname{kerja}\left(\mathrm{X}_{2}\right)$ naik maka akan diikuti oleh kenaikan kinerja karyawan Bagian Produksi PG. Meritjan Kediri (Y).

b) Secara simultan variabel kompensasi $\left(\mathrm{X}_{1}\right)$ dan disiplin kerja $\left(\mathrm{X}_{2}\right)$ berpengaruh secara nyata terhadap kinerja karyawan Bagian Produksi PG. Meritjan Kediri (Y). Dengan pengaruh hubungan yang positif yang berarti apabila variabel kompensasi $\left(\mathrm{X}_{1}\right)$ dan disiplin kerja $\left(\mathrm{X}_{2}\right)$ secara simultan naik maka akan diikuti oleh kenaikan kinerja karyawan Bagian Produksi PG. Meritjan Kediri (Y).

2. Saran

Dari hasil penelitian, analisis dan kesimpulan diatas, adapun saran-saran yang dapat disampaikan peneliti berkenaan dengan hasil penelitian ini adalah sebagai berikut:
1. Bagi Perusahaan
a. Pemimpin perusahaan harus mengkontrol karyawan dengan hasil CCTV yang ada diperusahaan dan melakukan evaluasi seminggu sekali tentang aktivitas kerja karyawan apakah ada kesulitan atau kerusakan alat-alat produksinya untuk meningkatkan kinerja karyawan Bagian Produksi PG. Meritjan Kediri.

b. Pihak Manajemen PG.. Meritjan Kediri diharapkan dapat lebih mengevaluasi dan meningkatkan kompensasi yang telah diberikan kepada karyawan Bagian Produksi PG.. Meritjan Kediri, sehingga dengan adanya hal tersebut, maka diharapkan perusahaan akan tetap membentuk adanya motivasi kerja yang baik yang akan mendukung adanya peningkatan kinerja karyawan Bagian Produksi PG.. Meritjan Kediri

c. Pihak Manajemen PG.. Meritjan Kediri diharapkan dapat lebih mengembangkan disiplin kerja yang telah diterapkan diperusahaan, sehinggaa dengan adanya hal tersebut, maka diharapkan perusahaan akan membentuk adanya karyawan yang bekerja sesuai dengan standar yang diharapkan oleh perusahaan untuk meningkatkan kinerja karyawan Bagian Produksi PG.. Meritjan Kediri

\section{Bagi Peneliti Mendatang}

Bagi peneliti mendatang yang ingin mengembangkan dan melanjutkan penelitian ini sebaiknya menambah variabel lain karena masih banyak faktor yang mempengaruhi kinerja karyawanBagian Produksi. Seperti, insentif, lingkungan kerja, pelatihan dan pengembangan. Sehingga dapat di ketahui sejauh mana peranan maing-masing teori tersebut yang merupakan alternatif yang lebih baik dalam menilai kinerja karyawan.

\section{DAFTAR PUSTAKA}

1. Arikunto, Suharsimi. 2010. Prosedur Penelitian, ed. Rev.,cet. Empat Belas. PT Rineka Cipta: Jakarta

2. Darsono dan Tjatjuk, Siswandoko. 2011.Manajmen Sumber Daya Manusia Abad 21. Nusantara Consulting: Jakarta

3. Davis, Keith dan Newstrom. 2000. Perilaku Dalam Organisasi, Edisi Ketujuh. Erlangga: Jakarta.

4. Dessler, Gary. 2006. Manajemen Sumber Daya Edisi Kesepuluh Jilid I. Terjemahan Paramita Rahayu.Klaten : Intan Sejati.

5. Ghozali, Imam. 2005. Aplikasi Analisis Multivariat dengan Program SPSS Cetakan ke-6. Badan Penerbit Universitas Malang.

6. Gorda, I Gusti Ngurah. 2006. Manjemen Sumber Daya Manusia. Astabrata Bali: Denpasar.

7. Handoko, T. Hani. 2001. Manajemen Personalia dan Sumber Daya Manusia, Edisi Kedua. BPFE: Yogyakarta.

8. Hasibuan, Malayu. 2008. Manajemen Sumber Daya Manusia. PT Bumi Aksara: Jakarta.

9. Mahmudi. 2005. Manajemen Kinerja Sektor Publik, Edisi I. UPP AMP YKPN: Yogyakarta. 
10. Malayu, S.P, Hasibuan. 2007. Manajemen Sumber Daya Manusia, cetakan kesembilan. Bumi Aksara: Jakarta.

11. Mangkunegara, A.A Anwar Prabu. 2006. Evaluasi Kinerja Sumber Daya Manusia. Refika Aditama: Jakarta.

12. Mas'ud. 2004. Survei Diagnosis Organisasional (Konsep dan Aplikasi). BP Universitas Diponegoro: Semarang.

13. Nasution.2003. Metodologi Research Penelitian Ilmiah. Bumi Aksara : Jakarta.

14. Nitisemito, 2000.Manajemen Personalia, Manajemen Sumber Daya Manusia. Ghalia Indonesia: Jakarta.

15. Robbins. 2006. Organizational Behavior. Edisi Bahasa Indonesia. PT Indeks Kelompok Gramedia: Jakarta.

16. Santoso, Singgih.2002. Mengolah Data Statistik Secara Prefesional.halaman 143-231 PT Elex Media Komputindo : Jakarta.

17. Sarwono, Jonathan. 2006. Analisis Data Penelitian Menggunakan SPSS 13.Andi : Yogyakarta.

18. Sedarmayanti.2007. Manajemen Sumber Daya Manusia dan Produktivitas Kerja. Mandar Maju: Bandung.

19. Setiyawan, Budi dan Waridin.2006. Pengaruh Disiplin Kerja Karyawan Dan Budaya Organisasi Terhadap Kinerja di Devisi Radiologi RSUP Dokter Kariadi Semarang.JRBI.Vol 2. No 2. Hal : 181182.
20. Siagian, Dergibson dan Sugiarto. 2002. Metode Statistika Untuk Bisnis Dan Ekonomi. PT Gramedia Pustaka: Jakarta.

21. Simamora, Henry. 2004. Manajemen Sumber Daya Manusia Edisi III. Yogyakarta : Penerbit STIE YKPN Yogyakarta.

22. Simanjuntak, Payaman J. 2005. Manajemen dan Evaluasi Kerja. Lembaga Penerbit FEUI: Jakarta.

23. Sugiyono. 2003. Metode Penelitian Bisnis Cetakan Pertama.CV Alfabeta: Jakarta.

24. Veitzal dan Sagala Jauvani.2009. Manajemen Sumber Daya Manusia untuk Perusahaan. Rajawali Pers: Jakarta.

25. Wibowo.2012. Manajemen Kinerja Edisi Ketiga.Pt. Rajagrafindo Persada: Jakarta.

26. Rafi. 2012. Analisis Pengaruh Lingkungan Kerja, Disiplin Kerja dan Kompensasi Terhadap Kinerja Organisasi pada PT Nusantara XI PG. Prajedkan. Jurnal.

27. Dini Krismasari dan Agus Frianto.2014. Pengaruh Kompensasi dan Displin Kerja Terhadap Prestasi Kerja Karyawan Pabrik Gula Tjoekir Jombang. Jurnal Ilmiah. Universitas Negeri Surabaya.

28. Firziyanah Mustika Utami. 2014. Pengaruh Kompensasi dan Disiplin Kerja Terhadap Kinerja Karyawan PT. Gapura Omega Alpha Land Depok.Skripsi.UIN Syarif Hidayatullah Jakarta. 